\title{
Śvetāmbara Jain Canonical Commentators Writing in Sanskrit ${ }^{1}$
}

\author{
Royce WILES*
}

\begin{abstract}
Jain commentaries in Sanskrit are vital for an understanding of the old Jain religious texts in Prakrit, the commentaries date from the $8^{\text {th }}$ to $13^{\text {th }}$ century. The major commentators are well-known in name but as yet there has not been any sustained research on their works. This article attempts to provide an initial reference point by listing (for the first time) all known published editions of Jain commentaries in Sanskrit on the Śvetāmbara canon by Śilanka ( $9^{\text {th }}$ century), Abhayadeva $\left(10^{\text {th }}\right.$ century) and Malayagiri $\left(10^{\text {th }}-11^{\text {th }}\right.$ century).
\end{abstract}

Keywords: Jainism, Śvetāmbara Jain texts, Sanskrit commentaries

\section{Izvleček}

Džainski komentarji, zapisani v sanskrtu, ki so nastali med 8. in 13. stoletjem, so ključnega pomena za razumevanje džainskega kanona, ki se je ohranil v prakrtu. Glavni komentatorji so sicer poznani po imenih, vendar so jim znanstveniki do sedaj namenili le malo pozornosti. Glavni doprinos prispevka je v celostni predstavitvi vseh obstoječih izdaj džainskih komentarjev na džainske tekste iz tradicije Śvetāmbara, ki so zapisani v sanskrtu, Pregled komentarjev je osredotočen na tri avtorje: Śílañka iz 9. stoletja, Abhayadeva iz 10. stoletja in Malayagiri iz 10.-11. stoletja.

Ključne besede: džainizem, džainski teksti tradicije Śvetāmbara, džainski komentarji v sanskrtu

\footnotetext{
${ }^{1}$ In bibliographic citations an asterisk $\left(^{*}\right)$ indicates a reference from a secondary source not seen personally; square brackets ([ ]) indicate material that is conjectural.

* Royce Wiles, PhD, Visiting Fellow, Australian National University (ANU), Canberra. royce.wiles@gmail.com
} 


\section{Introduction}

The layers of Jaina commentary literature have been surveyed by a number of scholars, nevertheless, "Jaina exegetical literature," as J. Bronkhorst has stated, still remains "vast, complicated, and little explored" (Bronkhorst 1999, 987). ${ }^{2}$ While editing a Jaina canonical text from manuscripts (the Nirayāvaliy $\bar{a}$ suyakkhandha), my attempts to compile information about the author of the only commentary on that text (Śrīcandra) revealed to me how problematic it was to find my way around that literature. I therefore surveyed earlier works and compiled original descriptive information about canonical commentaries. Existing surveys of the commentary works of the four commentators reviewed here are useful, but very limited. In chronological sequence the writers dicussed here are: Śilanika (fl. 850-876), ${ }^{3}$ Abhayadeva (fl. 1058-71), Malayagiri (between 1093 and 1193) and Śrīcandra (between 1103 and 1171). There is no easy way to know which commentaries of any of these authors have been published or when. By making the brief overview below I hope to provide a preliminary reference point for researchers delving into commentaries on the Śvetāmbara canon.

Only a subset of canonical commentators are included here, the (earlier) somewhat terse Prakrit commentaries (cūrnis) are excluded, as are those of significant authors like Haribhadra (fl. 770-790) (Williams 1965, 101-11) who began the process of shifting Jaina commentaries from Prakrit to Sanskrit. In many cases Haribhadra and authors like him simply transpose the material from Prakrit commentaries directly into Sanskrit (although at times adding useful clarifications). The recent article by Jyväsjärvi (2010) highlights some of the emerging issues in approaching the Jaina exegetical traditions.

The names of the major commentators on the canon writing in Sanskrit are familiar to all who attempt to read the canonical texts: unquestionably the most important are Śīanka, Abhayadeva, Malayagiri with the addition of Śrīcandra perhaps. There are few accounts of them and their work, certainly no comprehensive listing. Apart from volume three of the comprehensive and standard history of Jain literature in Hindi-Jaina Sāhitya kā Bṛhad Itihāsa (1967) - little sustained research has been published on these authors: for example

\footnotetext{
${ }^{2}$ Surveys have been made by Kapadia 1935; Schubring 1935 §43, Kapadia 2000, 171-205; Jaina Sāhitya kā Bṛhad Itihāsa 1966, v. 3; Alsdorf 1977; Jain 1984, 51-60; Khadabadi 1991; Dundas 1996; Norman 1997.

${ }^{3}$ The basis for dates used is examined below. All dates are cited as the Gregorian years, i.e. Common Era (CE) unless stated otherwise.
} 
none of the commentaries of the major commentators has ever been rendered into English. ${ }^{4}$ Below I will list as comprehensively as possible (for the first time to my knowledge) the known works - published and unpublished-of these four commentators.

There is a sequential and cumulative aspect to the commentatorial work, albeit with gaps; listing the canonical texts in their current sequence with the commentaries available shows that Abhayadeva apparently made comments on texts which his predecessor two hundred years earlier, Sīlānka, had not commented upon. A feature of the existing early Sanskrit commentaries on the Anigas and Uvānigas (all of which come after Haribhadra (fl. 770-790)) is that there is only one standard Sanskrit commentary on each Ariga and Uvāinga text (at least until well into the $16^{\text {th }}$ century $\mathrm{CE}$ when a few other commentaries began to be composed). Once a commentary had been produced in Sanskrit, it seems no one else felt it necessary (or possible?) to write one: Abhayadeva has not commented on the texts already commented on by Silānka, Malayagiri likewise has not commented on texts already dealt with by Śīānka or Abhayadeva. Śrīcandra does not however seem to quote Malayagiri either.

One explanation for this could be strong veneration for earlier teachers, an important element in Jaina monastic and lay practice. Writing a commentary on a text which already had a commentary by an earlier teacher would perhaps have been seen as disrespectful, especially if there were to be a difference of opinion. Neither the Ayārāinga nor Süyagada are straightforward texts so it cannot be argued that those texts were not in need of additional explication, nevertheless for some reason Abhayadeva chose not to make any comment on them. It could also have been that there was simply no further material available to add to the commentaries already written. This though did not apply to non-Änga, nonUvāinga texts, however; in medieval times there was a flood of commentaries on the Dasaveyāliya, Uttarajjhayaṇa, and Kappasutta. For those texts at least there

\footnotetext{
${ }^{4}$ A few commentaries have been translated in full into Gujarātī: (1) Śilāinka's on the Ayārāinga

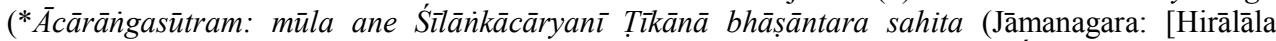
Hamsarāja] 1935))-(2) Abhayadeva's on the Thāna (Śrīsthānānigasūtram: Śrìmatsudharmasvāmigaṇabhrtprarūpitam: mūla tathā Śrī Candragacchālañkāra Śrīmad Abhayadevasūrițīkānā anuvāda yukta (Mundrā, Kaccha: Așțakoțī Bṛhadpakșīya Sañgha, Vīra saṃvat 2469-78 [1942-51]) - (3) Abhayadeva's on the Samavayāinga (published Bhāvanagara: Jeṭhālāla, Haribhāī, Jainadharma Prasāraka Sabhā, Vi. saṃ. 1995 [1938]), cited without full citation details in Devendra Muni 1977, 711) - and (4) Malayagiri's on the Pị̣danijjutti (Śrutakevali Bhagavanta Śr Bhadrabāhusvāmij̄̄ viracita Śrīpindaniryukti grantharatnano: Malayagirijī viracita țīkārthayuta suviśuddha anuvāda (Bhāvanagara: Śrī Śāsanakaṇțoddhāraka Jñānamandira: Vīrasaṃ 2488. Vi. sạ̣. 2018. Sane 1962. Śake 1883).
} 
seems not to have been any obstacle to multiple commentaries, either in Sanskrit or in the so-called vernaculars (Old Gujarati, Rajasthani etc.).

A related question is the process by which commentaries became "canonized" or "authorized," i.e. accepted as standard, this is far from resolved. There must have been some procedure (de jure or de facto) for the dispersal of new commentaries (and new works in general) and some process by which a late minor commentary, such as that by Śrīcandra, could be propagated. The life of wandering ascetic teachers is hardly conducive to centralized mechanisms of "authorizing" particular works. Perhaps the centres of manuscript copying were also centres for "authorizing" such commentaries. Pātạn could certainly have been one such centre to judge from the number of manuscripts in Jaisalmer collections which were copied there.

Each of the four commentators treated here will now be taken up and their canonical commentaries listed (with bibliographic citations). For a comprehensive assessment of each of the commentators access to the best of these published editions will be needed.

\section{Sílāñka (fl. 850-76)}

Two important canonical commentaries are attributed to Śîlānka ${ }^{5}$ on the first and second of the Jaina Angas, the Ayāraniga and the Süyagadariga respectively.

In terms of dating these two major commentaries, that on the Ayārāinga is dated to either Śāka era 784 [862 CE] (Velankar 1944, 24) or Śāka 798 [872] (Schubring 1935 §43); while the commentary on the Sūyagada is dated to Śāka 784, i.e. samvat 919 [862 CE] (same place as footnote 4 above) although other sources give Śāka 798 = saṃvat 933 [876 CE] (Velankar 1944, 450).

Leumann $(1934,15)$ dates this commentator to $870 \mathrm{CE}$ (references from Balbir $(1993,1,78))$. Kapadia, however, cites dates provided in manuscripts of Śīlānka's commentary on the first Ariga, ranging from Śāka 772-798 (850-876 CE) and prefers $876 \mathrm{CE}$ as the most likely $(2000,197)$. This information is repeated by

\footnotetext{
${ }^{5}$ Referred to as Śīlācārya on p. 66 ( $1^{\text {st }}$ group) of the following edition: Ācārāingasūtram

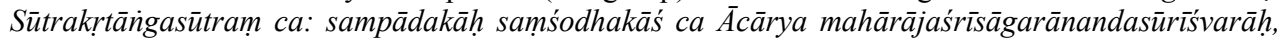
Munirājaśrīpunyavijayajīmahārājasàngrhitaprācīnasāmagryānusāreṇa śuddhi-vrddhipatrakādivivi dhapariśiștādibhih parișkartā Munih Jambūvijayah, sahāyako Muniḥ Dharmacandravijayaḥ. Dillī: Motīlāla Banārasīdāsa Iṇ̣olōjika Ṭrasṭa, 1978.
} 
Mehatā (Jaina Sāhitya kā Brhad Itihāsa 1966, v. 1, 382-87). I have chosen to use the more inclusive dates. Tieken, however, holds that Śilānka's date is uncertain $(1986,7)$.

\section{3 Āyārañga-sūtra Commentary}

The first text of the "canon" and a treatment of the way of life of a Jain monk. The important commentary by Śîlànka is referred to by a number of titles: Ayārānga-

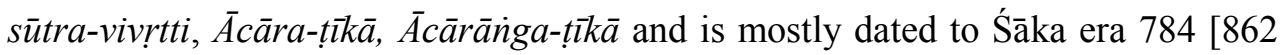
$\mathrm{CE}]$. It has an extent of "12,300 granthas" (Velankar 1944, 24) (the "grantha" (like the śloka) is a traditional unit of measurement of the extent of texts). The base text is not clearly comprehensible without the help of the commentary which has been printed a number of times:

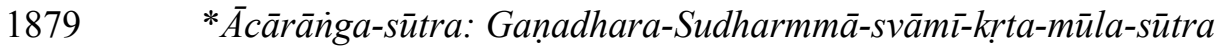
tadupari Śri-Hamsasūrikrta-Dīpikā-țīka Śri-Śïlangāeārya-krtaĀcārañga-țikà evam Śrī-Bhagavān-Pāyacandaji-krta-[Gujarātī]bhāṣā / Śrī-Bhagavān-Vijayasādhunā saṃśodhitaṃ. Kalakattā: Nūtana-Samıskrta Press 1936 [1879].

1916 Śrimadgaṇadharavarasudharmasvāmipran̄itam Śrutakevalibhadrabāhusvāmidṛdhaniryuktiyuktam, Śrīmacchīlañkācāryavihitavivrtiyutam [part 2 -vivaranayutam] Śrīācārāngasūtram. Mahesana: Āgamodayasamitị̣, Vīrasamvat 2442. Vikramasamvat 1972-73. Krāīṣta 1916. (Reprinted 1978).

1932 or $34 *$ [Ācārānigasutta with Śīlānka's commentary]. Mumbaī: Śrīsiddhacakra Sāhitya Pracāraka Samiti, 1932. Vikrama saṃvat 1991 [1934].

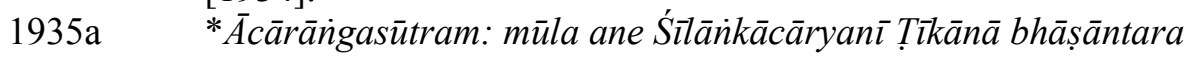
sahita / lakhoḥ Paṇ̣ita Hirālāla Haṃsarāja. Jāmanagara: [Hirālāla Hạ̣sarāja] 1935.

1935b *Śrī-Ācārañgam: Śrī-Bhadrabāhusvāmi-krta-niryukti-śrīŚìlāikācārya-krta-vrtti-yutam. Surat: Jainānanda Pustakālaya, 1935.

1935c *Mahāvīrasvāmino ācāradharma: Jaina Āgama "Ācārañga"no chāyānuvāda / sampādaka Gopāladāsa Jīvābhāī Pațela. 1. āvṛtti. Amadāvāda: Jainasāhitya Prakāśana Maṇụala. Prāptisthāna, Navajīvana Kāryālaya 1992 [1935].

1978 Ācārāingasūtram Sütrakrtāngasūtram ca / Śrīmatsudharmasvāmiviracitaṃ; BhadrabāhusvāmiviracitaniryuktiŚrīślāñkācāryaviracitaṭīkāsamanvitạ̣; sampādakāḥ saṃśodhakāśca Ācārya Mahārājaśrīsāgarānandasūrīśvarāḥ, Munirājaśrīpuṇyavijayajīmahārājasanggṛhitaprācīnasāmagryānusāreṇa śuddhi-vṛddhipatrakādi- 
vividhapariśișțādibhiḥ parișkartā Munị̣ Jambūvijayaḥ, sahāyako

Muniḥ Dharmacandravijayaḥ. Dillī: Motīlāla Banārasīdāsa Iṇ̣olājika Trasța, 1978. (Reprint of 1916 edition).

\section{Sūyagaḍa}

The Süyagada is one of the most important old texts of the canon and is a refutation of "heretical" doctrines. The commentary, the Sütrakrtāningațīka was composed in Śāka 784, i.e. samvvat 918 [861] other sources give Śāka 798, saṃvat 932 [875], 12,850 granthas (Velankar 1944, 450). It is important for assessments of the Jaina textual tradition to know that when writing this commentary Śīlanka did not have before him a single manuscript of the text representing the tradition for the older commentaries (cürnis) and he therefore had to simply take one exemplar as a standard. ${ }^{6}$

The Süyagada is an important text doctrinally and has been printed a number of times with one translation into Hindī in the 1922-32 edition.

1880 *Śrīsūyagadāinga-sūtra: dvitīyāingam, țikā tathā Bālāvabodha sahitam / Bhimasiṃha Mānekākhyā Śrāvakem pritipūrvaka prasiddha kodhum. Mumbapūrī: Nirṇayasāgara Mudrayantra, saṃvat 1936.

1917 Śrīmacchīlāìkācāryavihitavivaranayutam Śrīmatsudharmasvāmīganabhṛddrbdhạ̣ Śrīmatsūtrakṛtāngam. Mehesana:

Āgamodayasamiti, Vīrasamvvat 2443. Vikramasamvvat 1973. Krāișțasya san 1917.

1922-32 *[Sūya-gad̄āinga-sūtra: sațikānubhāṣāntara] / lekhaka Muni Māṇeka. Ahmedabad: Union Printing Press, 1922.

1936-40 *[Sūtrakrtângam: text with chāyā, niryukti, vyākarana, anvaya, bhāva and Sílāinka's Ṭīka (Hindī translation by Ambikādatta Ojhā)]. 1. āvṛtti. Rājkoța: Mahāvīra Jaina Jñānodaya Sosāyațī, Vikrama samvat 1993-97 [1936-40].

1950-53 Śrìmatsūtrakrtāñgam: Śrīsudharmasvāmisandṛbdhaṃ; Śrībhadrabāhusvāminirmitaniryuktiyutam, tadvrttikāraśrīmacchīlānkācāryavihitavivaranasuśobhitam, vividhapratyantarațīppanādyalañkṛtạ ca / samśodhakāh sampādakāśca Śrīmadācāryacandrasāgarasūrivarāḥ. Mumbaī: Śrīgoḍīpārśvanāthajainaderāsarapeḍhī, Vīrasamvat [2476?]-2479 [1950-53].

\footnotetext{
6 “[I]ha ca prāyah sūtrādarśeșu nānāvidhāni sūtrāṇi dṛśsante, na ca țikāsamvāāi eko'py ādarśah samupalabdhah, ata ekam ādarśam añgīkrtya asmābhir vivaranam kriyata iti, etad avagamya sūtravisamvvādadarśanāc cittavyāmoho na vidheya iti" (Sütrakrtānga-țikā, folio 336-1, cited in (Nandisuttam 1968, Editors' note, p. 97 (4th group) fn.2)).
} 


\section{Abhayadeva (fl. 1058-71) ${ }^{7}$}

Remarkably, there has not yet been a comprehensive study of this major Jaina commentator, or his works. There is, however, an important compilation of information in Hindī by Mehatā in the invaluable Jaina Sāhitya kä Brhad Itihāsa (v. 3, 316-414).

In addition, Dundas has also made a detailed presentation of the views of two Jaina intellectuals in medieval times about scriptural commentary within the Jaina tradition. His account focuses on Abhayadeva, "Jainism's greatest scriptural exegete" $(1996,74)$, and the later figure Dharmasāgara $\left(16^{\text {th }}\right.$ century). In that article Dundas has made a survey of hagiographies of Abhayadeva, focusing on Jinapāla's Yugapradhānācāryagurvāvali -written in 1248 - and Prabhācandra's Prabhāvakacarita-written in 1277 (1996, 79-84). According to Dundas, Abhayadeva may have became a Sūri, that is "a senior teacher authorized to interpret the scriptures," in 1063 and then begun his ambitious commentarial enterprise (Dundas 1996, 79). ${ }^{8}$

I have given below a listing of Abhayadeva's works (published and unpublished). ${ }^{9}$ The first are commentaries on canonical texts (listed in the current "standard" sequence for canonical texts), subsequent works are simply listed in alphabetically.

\section{Commentaries by Abhayadeva}

1. The text known as the Sthānänga provides (in numerical sequence) definitions and themes relevant to teachings of the Jains (much like the Ainguttara-nikāya of the Theravāda Tipițaka). Abhayadeva's commentary, the Sthānāinga-sūtra-bhāssya, also termed a tikk or a vivarana, was composed in samvat 1120 [1063], and is reputedly 14,250 granthas in extent (Kapadia 1935, v.17: 1, 62-63; Velankar 1944, 454).

1880 Sthānāinga sūtra: tritīyānga: Ganadhara Sudharma Svāmi sañkalita sūtra tadupari Śrimadabhayadeva Sūri kṛtā Samskrta țikā aura

\footnotetext{
${ }^{7}$ Most scholars cite merely " $10^{\text {th }}$ century" for Abhayadeva. The date range given here follows from the dates available for his commentaries on the Uvavaìya and Viyähapannatti respectively.

${ }^{8}$ Velankar $(1944,64)$ however, dates Abhayadeva's Uvavāiya commentary to samvat 1115 [1058 $\mathrm{CE}]$ but does not cite a source.

${ }^{9}$ Tripāthī $(1981,305)$ lists details of another work ascribed to Abhayadeva, the Bandhaśațtrimśikā published 1918-21.
} 
Megharāja kṛta bhāṣā țīkā yuta / Bṛhannāgarī Lauṅkagacchīya Vācanācārya Śrīrāmacandragaṇi śișya Ṛ̣i Nānakacanda se saṃśodhita hoke mudrita huvā. Banārasa: Jaina Prabhākāra Jātau, samviat 1937. Īsavī san 1880.

1918-20 Śrìmatsudharmasvāmiganabhrtprarūpitam

Śrīmaccandragacchālañkāraśrīmadabhayadevasūrisūtritavivaranayu tạn Śrīmatsthānāngasūtram. Mehesana: Śr̄āgamodayasamitị̆, Vīrasamvat 2445. Vikramasamvvat 1975. Krāișța 1918-20. (Reprinted 1985).

1937 *[Sthānānga-sūtra with Abhayadeva's commentary / edited by Muni Vallabhavijaya]. 2. āvṛtti. Ahmedābāda: Mānekalāla Cunīlāla va Kāntilāla Cunnīlāla, 1937. (Cited in Jaina Sāhitya kā Bṛhad Itihāsa, v. 1, 217, item a).

1985 Sthānānigasūtram Samavāyānigasūtram ca: dvādaśāingyām tritīyạ̣ caturtham ca / Pañcamaganadhara-

Bhagavatsudharmasvāmiviracitam; Ācārya pravaraśrīabhayadevasūriviracitavṛttisamalannkṛtaṃ; sampādakāḥ saṃśodhakāś ca Ācārya Mahārājaśrīsāgarānandasūrīśvarạ̣̄; Munirājaśrīpunyavijayajīmahārājasañgṛhītaprācīnasāmagryādyanusāraṃ vihitena śuddhipatrakeṇa tathā aparair api nānāvidhaị̣ pariśiștạdibhị̣ parișkartā; Muniḥ Jambūvijayaḥ. 1. saṃskaraṇa. Dillī: Motilāla Banārasīdāsa Iṇ̣̣olājikala Țrasța, 1985. (Reprint of 1918-20 edition). $2002 *$ Sthānāingasütra with the commentary by Abhayadeva Suri / edited by Muni Jambūvijaya]. Bombay: Śn̄i Mahāvīra Jaina Vidyālaya, 2002-2003.

2. The Samavāya very much continues the preceding Ainga text, the Sthānānga, and provides enumerations and lists of teachings. The Samavāyānga-sūtra-vrtti is variously termed a vrtti, vivrti or țikka and was composed in samvat 1120 [1063].

1880 *Atha țīkāvarttikāsaṃvalitạn Samavāyāniga: caturthāñgasūtram prārambhyate. Banārasa: Jaina Prabhākara, saṃvat 1937. 1880.

1917 *[Samavāyāinga sūtra with țīkà of Abhayadeva] / sampādaka Nagīnadāsa Nemacanda. Amadāvāda: Śeṭha Māṇeklāla Cunīlāla, samvat 1974 [1917].

1918 Śrìmatsudharmasvāmiganabhrịviracitam Cāndrakulinanavāninivirttikārakaśrimmadabhayadevasūriviracitațīkopetam Śrīsamavāyānigasūtram. Mehesana: Śrīagamodayasamitị, Vīrasaṃvat 2444. Vikramasaṃvat 1974. Krāișța san 1918.

1938 *Samavāyānigasūtram: sampurnam / Abhayadevasūrisūtritavivaranayutam; sampādakaḥ Maphatalāla Jhaveracandra. Ahamadābāda: Țhe. Bhattīnīvārī, 1938. 
1985 Sthānāngasūtram Samavāyānigasūtram ca: dvādaśāngyām trịtȳyạ caturtham ca / Pañcamaganadhara-

Bhagavatsudharmasvāmiviracitam; Ācārya pravaraśrīabhayadevasūriviracitavṛ̣ttisamalañkṛtaṃ; sampādakāḥ saṃśodhakāś ca Ācārya Mahārājaśrīsāgarānandasūrîśvarāḥ;

Munirājaśrīpunyavijayajīmahārājasangg̣hītaprācīnasāmagryādyanusār ạ̣ vihitena śuddhipatrakena tathā aparair api nānāvidhaih pariśiștāadibhiḥ pariṣkartā; Muniḥ Jambūvijayaḥ. 1. saṃskaraṇa. Dillī: Motilāla Banārasīdāsa Iṇụolājikala Țrasța, 1985.

1989 Śrī Samavāyāñga sūtram: Śrìmadganadharadevavinirmitam

Sūripurandaraśrìmadabhayadevasūrīśvara-Vrttiyutạn caturthānga / sampādakaḥ saṃśodhakaś ca Vijayajinendrasūriśvaraḥ.

Prathamāvṛtti. Lākhābāvala Śāntipurī, Saurāștraḥ: Śn̄̄

Harșapuṣpāmaṛta Jaina Granthamālā, Vīra saṃ. 2515. Vi. saṃ. 2045. San 1989.

3. The base text, the Bhagavatī is a very large compendium of Jain dogmatics, partly presented as questions and answers, with Mahāvīra responding to his principal disciple Goyama Indabhūti (Winternitz 1933: 2, 442-43). The Bhagavatī-sütra-vrtti (also called -țīkā, -vivrti, -vivarana) was composed in 1128 [1071] with the help of Yaśaścandra Gaṇi and revised by Droṇasūi (Schubring 1944, 9; Velankar 1944, 290; Kapadia 1935, 17: 1, 86). It is reputedly 15,616 ślokas in extent and mentions a mūla tịka and the "cūrnikāra" a number of times (1994 edition, Bhūmikā 1, 38-39).

1881 *Atha Bhagavatī-sūtra-pañcamāninga-prārambha: LauñkāgacchīyaŚrī-Rāma-candra-Ganikrtra-Samskṛtānuvāada-yuta / GaṇadharaSudharma-Svāmi-sańkalita sūtra tadupari Śrìmad-Abhayadeva-Sūrikṛta Saṃskṛta-țikāa aura Megharāja-Gaṇi-kṛta [Gujarātī]-bhāṣā-țîkāyuta. Benares: [s.n.], samvat 1938 [1881].

1917-31 Śrīmadbhagavatīsutra (Vyākhyāprajñaptih) / Bhagavatsudharmasvāmipranītam;; Śrīmadabhayadevasūriviracitavivaraṇasahitaṃ; Paṇditabecaradāsena anuvāditaṃ-saṃśodhitaṃ ca. Mumbaī: Śrījināgamaprakāśasabhā, Vi. sam. 1974-88. [1917-31].

1918-21 Śrīmadbhagavatīsūtram / Śrīmatsudharmasvāmigaṇibhṛtprarūpitạ̣ Śrīmadgautamagaṇadhārivācanānugataṃ; Śrīmaccandrakulālañkāraśrīmadabhayadevasūrisūtritavivaraṇayutam. Mehesana: Āgamodayasamiti, Vīrasamuvat 2444-47. Vikramasaṃvat 1974-77. Krāișța 1918-21.

1994-2007 Bhagavaī Viāhapannattī: mūlapātha, Samskrta chāyā, Hind̄̄ anuvāda, bhāṣya tathā pariśișta-śabdānukrama ādi: Jinadāsa 


\begin{abstract}
Mahattara krta Cūrṇi evam Abhayadevasūrikrtta Vrtti sahita I sampādaka bhāṣyakāra Ācārya Mahāprajñā [; Saṃskṛta chāyā, anuvādaka Sādhvī Pramukhā Kanakaprabhā]. Lāḍanūṃ, Rājasthāna: Jaina Viśvabhāratī Saṃsthāna, 1994-2007.
\end{abstract}

4. The base text is a compilation of important religious narrative tales. The commentary is termed the Jñata-dharma-kathä-vivarana or vrtti, and was composed in samvat 1120 [1063].

1876 *Jñātādharmmakathānga-sūtra: șașthama añga / Gaṇadharasudharmāsvāmīkṛtamūlasūtra tad upari Śrīmadabhayadevācāryya Sūrikṛtā țīkā; Vijayasādhunā samśodhītaṃ. Kalikātā: Nūtana Saṃskṛta Yantra, saṃvatsare 1933 [1876].

1919 Śrīmat Jñātādharmakathāingam:

Candrakulālan̄kāraśrīmadabhayadevasūrisūtritavivaranayutaṃ.

Mehesana: Āgamodayasamiti, Vīrasaṃvat 2449. Vikrama saṃ. 1975. Krāișta 1919.

1951-52 Śrījñātādharmakathāingam:

vartamānaśāsanamānyasūtrakārapañcamagaṇadharapravaraśrīsudharmasvāmisandṛdham, tatsūtrārtharahasyakāraśrimadbhadrabāhusvāminirmitaniryuktiyutam, navānigīvrttikāraśrimadabhayadevasūrivihitavivaranasuśobhitam, sampādakīyavividhapratyantarapāthādyanekapariśisțtasamalaìkrtam ca / samśodhakaḥ sampādakaś ca Ȧcārya Śrīcandrasāgarasūriḥ.

Mumbāi: Śrīsiddhacakra-sāhityapracārakasamiti, Vīrāsamvvat 247879 [1951-52].

1987 Śrī Jñāta-dharmakathāngam: pūjya Ganadharapranītam navāngivrttikāra-pūjyāāāryapungava Śrimadabhayadevasūriśvaravivịtam șaștham anga / sampādaka [sic] saṃśodhakaś ca Śrīvijayajinendrasūriśvarah ... . Prathamāvṛttih. Śāntipurī, Bāyā, Jāmanagara: Śrī Harṣapuṣpāmṛta Jaina Granthamālā, Vīra sam[vat] 2513 [1987].

5. The Uvāsagadasāo expands on the ten duties of a lay person and is mostly narrative in content. The commentary, the Upāsaka-daśä-vivaraṇa was composed in samvat 1120 [1063] (Hoernle 1880, 2, xxi).

1876 *Upāsakadāśasūtra: saptama añga /

Gaṇadharasudharmāsvāmīkṛtamūla sūtra tadupari

Śrīmadabhayadevācāryya Sūrīkṛtațīkā; Śrī Bhagavān Vijayakṛta

[Gujarātī] bhāṣā saṃśodhīta. Calcutta: s.n., 1933 [1876].

1880-90 *The Uvāsagadasāo, or, The religious profession of an Uvāsaga, expounded in ten lectures, being the Seventh Anga of the Jains, edited 
in the original Prākrit with the Sanskrit commentary of Abhayadeva [and English translation] / by A. F. Rudolf Hoernle. Calcutta: Asiatic Society of Bengal, 1890, 1880.

1920a Śrimaccandrakalīna [sic] Śrimadab[h]ayadevācārya vihitavivaranayutaṃ Śrīmadupāsakadaśāingam. Mahesāṇā: Āgamodayasamiti, Vīrasaṃvat 2446. Vikramasamvat 1976. Krāisțasan 1920.

1920b *[Text and Abhayadeva's commentary]. Bhavnagar: Jaina Ātmānanda Sabhā, saṃvat 1977.

1935 Upāsakadaśänigam: Śrimadabhayadevasūriviracitavrttisahitam [with Gujarātī translation of Abhayadeva's Ṭīkā] / by Bhagavānadāsa Harșacandra. Ahamadābāda: Jaina Sosāițī, Vi. saṃ. 1992 [1935].

6-7. The Anuttarovavāiyadasāo is a narrative of the lives of holy individuals who starve themselves to death, the Antagadadasāo is similar. The commentaries, the Anuttaropapātika-daśā-vrtti, and Antagadadasāo commentary are a single collective commentary on three related texts with similar content, the Uvāsagadasāo, Antagaḍdasāo and Anuttarovavāiya. The commentary was very likely composed in samvat 1127 [1070] (stated at the end of the Anuttarovaväiya commentary (see the Uvasagadasāo edition of 1880-90 listed above (vol. 2, xxi))).

1920 *Śrīmad-Aṃtakṛd-daśānuttaropapātika-daśāa-Vipāka-śrutāni: ... Abhayadevācārya-vihitavivarana-yutāni. Mahesana: The Agamodaya Samiti, 1920.

1921 Śrīanuttaropapātikadaśāh: Śrimatsudharmasvāmiganabhrdviracitam Cāndrakulābhūṣana-śrimadabhayadevasūrikrtavrttiyutāḥ: sāvacūrikam Pudgalaparāvarttastotrañ ca / Dānavijayena samśodhitam. Bhāvanagara: Śrīatmānandajainasabhā, Vīrasamvat 2447. Ātmasamvat 25. Vikramasamvat 1977. San 1921.

1932 The Antagada-dasāo and the Anuttarovavāia-dasāo, the eighth and the ninth Angas of the Jaina canon = Nigganthapāvayanesu ațthamanavamañgabhūyāo Antagad̄ānuttarovavāiyadasāo / edited with introduction, translation, notes and appendices by M. C. Modi. 1. edition. Ahmedabad: Gurjar Granth Ratna Karyalay, 1932.

1984 *Śrīmadantakrddasāngam-Srīmadanuttaropapātikadasāingañ ca: aștamam navamam cāngasūtram / Sudharmasvāmipraṇītam: Srīmadabhayadevasūrikṛtavṛ̣ttisahitaṃ; mūla-țīà tathā mūla ane țīkānā Gurjarānuvāda sahita; punarmudraṇā preraka tathā sampaādaka Aruṇavijayajī Mahārāja. 1. Āvrttti. Mumbai: Śrī Mahāvīra Jaina Sāhitya Prakaśana, 1984. 
8. The base text is a puzzle, the contents as we have them do not match the title well. ${ }^{10}$ The Praśnavyākarana-vivarana (also called -vivrti or țika ) was corrected by Droṇasūri (Velankar 1944, 274).
1876
*Praśnavyākaranakasūtra: dasama añga/
Gaṇadharasudharmasvāmīkṛtasūtra tadupari
Śrīmadabhayadevācāryya Sūrīkṛta țịkā; Śrībhagavān Vijayakṛta
[Gujarātī] bhāṣā samśsodhita. Calcutta: Nūtanasaṃskṛtayantre, 1933
$1919 \quad$ *Śrīpraśnavyākarañāingam:
Śrīmatsudharmasvāmigaṇabhrtprarūpitam
Śrīmaccandrakulālañkāraśrimmadabhayadevasūrīsūtritavivaranayuta
$m$. Bombay: Āgamodayasamiti, Vīrasaṃvat 2445. Vikramasaṃvat
1975. Krāișta 1919.
1989 Sūripurandara-Cāndrakulina-Śrimadabhayadevācāryadevadṛdha- vyākhyāyutam Śrīmadganadharadeva pranītam Śrī Praśnavyākarana daśā sūtram / sampādaka [sic] saṃśodhakaś ca
Vijayajinendrasūrīśvaraḥ. Prathamāvṛtti. Lākhābāvala Śāntipurī, Saurāṣtra: Śr̄̄ Harșapuṣpāmṛta Jaina Granthamālā, Vīra saṃ. 2515. Vikrama sam. 2045. San 1989.

9. The base text, the Viväga-sutta, outlines the consequences of various actions, stories of the effects of good and bad actions. The commentary is called the Vipāka-sütra-vrtti of about 1,000 granthas in extent (no date linked to it) (Velankar 1944, 357).

1876 *Vipākasūtra / Gaṇadhara Sudharmasvāmikṛtamūlasūtra, tadupari Śrīmadabhayadevācaryya Sūrikṛtațīkā; Vijayakṛtabhāṣā saṃśodhitā. Kalikatā: Nutanasaṃskrtayantra, saṃvat 1933 [1876]. *Śrī-Vipāka-śrutam: Śrīmad-Abhayadeva-Süri-pranīta yā vrttyā vibhūṣitam Śrī-Sudharma-Svāmī-vinirmitam ... / Pạ̣ditaHaragovinda-Dāsena saṃśodhitạ̣ Saṃskṛtacchāyayā vibhūṣitạ̣ ca. Calcutta: Bhāratīya-Jaina-Siddhānta-Prakāśaka Press, 1976 [1919].

$1920 \quad *$ Śrīmad-Antakrd-daśānuttaropapātika-daśā-Vipāka-śrutāni: Abhayadevācārya-vihitavivara-yutāni. Mahesana: The Agamodaya Samiti, 1920.

1933 The Vivāgasuya = Vivāgasuyam, the eleventh Anga of the Jaina canon, edited for the use of university students, with introduction, glossary and notes / by P. L. Vaidya. Poona: P. L. Vaidya, 1933.

\footnotetext{
${ }^{10}$ See Acharya (2007) for a possible resolution of the problem, he announces the potentially important discovery of a $12^{\text {th }}$ century palm-leaf text in Kathmandu which may be the original (lost) version of the base text although it may also be of Digambara lineage or only part of the complete text which Abhayadeva mentions has been lost.
} 
10. The Aupapātika-sütra is largely narrative and gives the fullest version of descriptive passages which are abbreviated radically in other canonical texts (see Winternitz 1933:2, 454). The Aupapātika-sūtra-vrtti was composed in samvat 1115 [1058] (Velankar 1944, 64).

1879 Śrī Ubabāīsūtra: prathama upāinga / Gaṇadhara Śrī Sudharmmā Svāmī krta mūlasūtra, taduparī Șaratharagache Śrī Abhayadeva Surī kṛta țịā: taduparī Lupakagache Śrī Amrtacandra Surī kṛta Bālābodha; Śrī Satyavrata ke dvārā saṃśodhita hokara. Kalakattā: Śrī Satyavrata, samvat 1936 [1879].

1916 Śrīcaturdaśapūrvadharaśrutasthavirapran̄itam Candrakulīnaśrìmadabhayadevasūrivihita-śrīmaddronāeāryaśodhitavrttiyutam Śrīmadaupapātikasūtram. Mehesana: Āgamodayasamiti, Vīra saṃvat 2442. Vikramasamvat 1972. Krāișța 1916.

1985 Śrī Aupapātikasūtram: Śrīmaccaturdaśapūrvadharaśrutasthavirasañkalitam Śrīmadabhayadevasūriśvara sandṛdha-Śrīmaddronāeāryasamșodhitavivaranayutam / sampādakaḥ saṃśodhakaś ca Vijayajinendrasūrīśvaraḥ. Prathamāvṛtti. Lākhābāvala, Sāntipurī, Saurāṣtra: Śn̄̄ Harșapuṣpāmṛta Jaina granthamālā, Vīra 2511. Vikrama sam. 2041. San 1985.

11. The Prajñapana gives "in 36 chapters a classification of living beings, containing under 'human being' a geographical-ethnographic outline, in which the Aryans (ariya, arrya) and the barbarians (milikkha, mleccha) are enumerated with their habitations" (Winternitz 1933: 2, 456). The Prajñapanopāinga-trtīya-padasangrahañi is a partial commentary also known as the Prajñāpana-trtīyapadasangrahan̄i or -samgahan̄i, it is 150 granthas in extent (Kapadia 1935, 17, 1, 205).

1917-18 *Navāngi-vrtti-kāra-Śrīmad-Abhayadeva-Sūri-racite Pañcanirgranthi-Prajñāpanopāingatrttīya-pada-sangrahan̄i-prakaraṇe (sāvacūrnike) / Muni-Caturavijayena samśodhite. Bombay: Nirnayasāgara Press, 1974 [1917-18].

Other works attributed to Abhayadeva can be mentioned here: (12) Jayatihuanastotra, (13) the Pārśva-jina-cintāmani-stuti, (14) the Saptatikā-bhāsya, (15) Jayantavijaya, (16) a commentary on Jinacandra Gaṇin's treatise, Navatatttvaprakarana (about $1063 \mathrm{CE}$ ), and (17) a commentary on Haribhadra's treatise, Pañcāśaka-sūtra / -prakarana: composed around 1067). 


\section{Malayagiri (c. 1093-1193) ${ }^{11}$}

Although Malayagiri as one of the most prominent Śvetāmbara scholars and is famous as a contemporary of Hemacandra, little is known about this major commentator. The following paragraphs summarize statements about him made by one or two earlier scholars (in Hindi). I then list his commentaries on canonical texts along with details of published editions. ${ }^{12}$

There are apparently only two places in his works where Malayagiri refers to himself. The first is in colophons containing lines such as yad avāpi Malayagirin̄a siddhim tenāśnutām lokah — "whatever [merit] has been obtained by Malayagiri, may the world experience the result of that"-and similar verses at the end of his works (e.g. of the Jyotișkarandakavrtti, Nandīvrtti, Rāyapasenaijjavrtti). The opening of his Śabdānuśáśana has: evam krta-māngala-rakșāvidhānah paripūrṇam alpagrantham laghūpāyam Ācāryo Malayagirih Śabdānuśāsanam ārabhate (Malayagiri 1967) i.e. "the Ācārya Malayagiri ... undertakes the work entitled Teachings about Words." There is no other explicit information in his works.

Turning to external sources, Muni Punyavijaya has stated in his introduction to the editions of the fifth and sixth Karmagranthas - taken here from the repetition of it in Jaina Sāhitya kā Bṛhad Itihāsa (v. 3, 415-39) - that Malayagiri was a contemporary of Hemacandra (1088-1172). The only evidence cited is the hagiographical account in Jinamaṇdana Gani's Kumārapālapratibodha,which is dated to 1492 [1435] (Velankar 1944, 93). ${ }^{13}$ The account there is that Hemacandra, on the command of his guru, was travelling with two individuals of other gacchas, Devendra Sūri and Malayagiri, en route to eastern India (Gauḍadeśa), where all three aimed to pursue their studies. On the way, in the village of "Khillūra," there was a sick [Jain] $s \bar{a} d h u$. The three travellers tended to him. That $s \bar{a} d h u$ was intent on journeying to Mount Raivataka (Girnār). Having arranged with the village

\footnotetext{
${ }^{11}$ Malayagiri's life appears to overlap that of Śrīcandra, because Malayagiri has produced more important commentaries, I have chosen to list his works first, which is also in keeping with the currently established sequence of texts.

${ }^{12}$ Sources for this information are: (1) Punyavijaya in the Prastāvanā to v. 5 and 6 of Devendra Sūri's (13 ${ }^{\text {th }}$ century) *Sațikah karmagrantha (Bhavnagar: Shri Atmanand Jaina Sabha, 1934-40) - (2) Mohanlāl Mehatā in (Jaina Sāhitya kā Brrhad Itihāsa (1966 v. 3, 415-39)-(3) Sirisāmajjavāyagaviraiyam Paṇnavan̄āsuttam (1969 v.2, 426-31) - (4) (Doshi, Malayagiri's Śabdānuśāsana 1967, Preface) - (5) Devendra Muni 1977, 524-34-(6) Prana Natha and Jitendra Bimala Chaudhuri,1938 Malayagiri s.v.

${ }^{13}$ Jinamandiana Gaṇi was of the Tapa gaccha. This work is in Sanskrit verse and prose. According to the Velankar 1944 entry, it was published in Bhavnagar, saṃvat 1971 [1914] in the Jaina Ātmānanda Sabhā series (no 34).
} 
people to somehow take him there in a suspended chair (doli ) to fulfill his last wishes, they all went to sleep. When they awoke, all three found themselves on Mount Raivataka. The goddess of the teaching (śäśana-devi) appeared and told them that their tasks would be completed there at that tirtha, so there was no need to go to the east. The goddess showed them many mantras, medicines and so forth and then disappeared. Later the three used the Siddha-cakra-mantra to please a certain god who granted them a boon each: Hemacandra's was that he could convert the king; Devendra Süri's that he could take a temple from the city of Kāntī to the village of Serīsaka in one night; Malayagiri's was that he could write commentaries on the Jaina Siddhānta. On the basis of this account, Punyavijaya assumes that Malayagiri had some scholastic connection with Hemacandra. Muni Punyavijaya has presented the traditional hagiographical account, which is some three hundred years later than the time to which it refers. This is not the strongest evidence for establishing Malayagiri's dates, and Doshi (whose views will be treated next) rejected this source as "more of a myth than a fact" (Doshi 1967, 3).

The next piece of evidence cited by Punyavijaya is that Malayagiri says in his Ávaśyakavrtti, tathā cāhuh stutișu guravah - "and the teachers say in works of praise." Malayagiri then cites a verse which also appears in Hemacandra's Anyayogavyavacchedadvātrimśika. This is taken to show that Malayagiri is referring deferentially to Hemacandra before citing from that scholar's work. As proof, however, this is not as convincing as another quotation in the Śabdānuśāsana, which appears in the Krdanta-pāda (§1.23) (Doshi 1967, 258) and is followed by: Ācārya Śrihemacandrah. This citation, which shows the link more distinctly, was first pointed out by Doshi in his edition of that grammatical text.

In his preface to the Śabdānuśāsana Doshi relies on a single sentence in the grammar-adahat arātīn Kumārapālah̆, "Kumārapāla destroyed his foes" (Doshi 1967, 278) - to argue that the use of the imperfect tense suggests that Malayagiri was recounting his personal experience, since that is the grammarians' view on the purpose of the imperfect. Therefore, Malayagiri and king Kumārapāla were contemporaries according to Doshi. Having established that the traditional date for king Kumārapāla coming to the throne is samvat 1199 [1142] (Doshi 1967, 4) and allowing a number of years for him to have conquered his enemies, Doshi thinks Malayagiri composed his grammar in about samvat 1227 [1170] (Doshi 1967, 4,9). However, he proceeds to suggest — on rather thinner grounds - that although the two scholars may have been contemporaries, Hemacandra was perhaps more than 
fifty years older than Malayagiri (Doshi 1967, 9). Doshi goes on-more reasonably perhaps - to assume that because the only other ascetic known to the tradition whose name ended in -giri was a brahman, therefore it is possible Malayagiri too was a brahman ascetic before he became a Jaina (4). As stated above, from a number of Gujarati words used in the commentaries Doshi also implies that Malayagiri was either from Saurāsțra or at the least very familiar with the language of that area (Doshi 1967, 5).

Doshi suggests that a number of the words used by Malayagiri show that he was a speaker of Saurāșțrī and a native of Saurāșțra (Doshi 1967, Introduction 5). In Abhayadeva's works too, to elucidate the word tellakela "an oil jar" the explanation given is: Saurāștra-prasiddho mrnmayas tailasya bhājanaviśesah, i.e. it is "a special oil container made of clay, well-known in Saurāștra" (this phrase is also taken over by Śrīcandra). It may have been that the centre of commentary writing was Gujarat.

Summarizing these date suggestions, Punyavijaya would have Malayagiri's life roughly around about that of the great Hemacandra (1088-1172), while Doshi suggests Malayagiri wrote his first work (the grammar) around 1170 and his remaining works after that date. Schubring has also cited secondary sources suggesting Malayagiri's grammar was written between 1143 and 1173 (Schubring 1935, 59) (Between samvat 1200 and 1230). Dundas, however, has given simply "13th century" as the approximate date of Malayagiri $(1996,78)$. It does not seem possible to be make the date more exact, and so I have preferred the larger date range of 1093-1193 for an indicatory period of Malayagiri's work. I would also suggest that it is possible the later commentator Śrīcandra wrote the Nirayāvaliyāsuyakkhandha commentary merely to complete the set of commentaries on the Ārigas and Upāingas already created by Śìlànka, Abhayadeva and Malayagiri. ${ }^{14}$

\footnotetext{
${ }^{14}$ See also Sirisāmajjavāyagaviraiyam Paṇnavaṇāsuttaṃ, sampādakāḥ Punyavijayo Muniḥ ... [et al.] (Bambaī: Śrī Mahāvīra Jaina Vidyālaya, Vīra saṃ. 2495-97 [1969-71]), vol. 2, 426-31 and Winternitz (1933: 2, 592). Pandịt Sukhalāla Sanghavī in the introduction to his Tattvārthasūtra (Ahmedabad: L. D. Institute, 1974, 62) refers to the introduction of the Dharmasaingrahani (presumably the edition of 1916 by Muni Kalyānavijaya) for information on the works of Malayagiri.
} 


\section{Commentaries by Malayagiri}

1. It is best to distinguish between two texts bearing the name Avassaya-sutta, the first being a brief canonical text commented on by Haribhadra and Malayagiri, the second a less ancient text still in liturgical usage, more frequently called SadĀvaśyakasūtra. Malayagiri's Āvaśyaka-vivarana is incomplete, but still, 18,000 ślokas in extent (Devendra Muni 1977, 525, 532-33).

1928-36 Śrīmanmalayagiryācāryakṛtavivaranayutam, Śrutakevaliśrīmadbhadrabāhusvāmisūtritaniryuktiyuta-Śrīâvaśyakasūtram. Bombay: Śrīagamodayasamiteh, Vìrasamvat 2454-62 [1928-36].

2. The Bhagavat $\bar{\imath}$ is a very large compendium of Jain dogmatics, partly presented as questions and answers, with Mahāvīra responding to his principal disciple Goyama Indabhūti (Winternitz 1933: 2, 442-43). The Bhagavati-vrtti is a commentary on the second śataka only of the Viyāhapannatti (Velankar 1944, 290) of 3,750 ślokas (Devendra Muni 1977, 525) but seems never to have been printed.

3. The Brhatkalpa is the principal work on the rules and regulations for monks and nuns, including restrictions concerning food, residence, etc. Malayagiri's Bṛhatkalpapițhikāvrtti, seems to be incomplete in 4,600 ślokas (Devendra Muni 1977: 525, 533-34). According to some, Malayagiri's work was completed by Kșemakīrti, pupil of Vijayendu of the Cāndrakula, in samvat 1332 [1275] (Velankar 1944, 284b; Kapadia 1935, 17: 2, 237-44; Jaina Sāhitya kā Bṛhad Itihāsa 1966, 3, 454), however Schubring states that Malayagiri's work was continued by Bālaśiraḥśekhara and gives Kșemakīrti as the author of a separate Vrtti (Schubring 1935, §51).

1933-43 Sthavira-Āryabhadrabāhusvāmipranītasvopajñaniryuktyupetạn Bṛhatkalpasūtram: Śri-Sanghadāsaganikșmāśramanasañkalitabhāsyopabrmhitam: Śrimadbhir Malayagirisūribhih prārabdhayā Vrddhapośälikatapāgacchīyaịh Śrīkșemakīrtyācāryaih pūrnịkrtayā ca vrttyā samalankkrtam / tat sampādakau Munī CaturvijayaPunyavijayau. Bhāvanagara: Srījaina-Ātmānandasabhā, Vīrasamvat 2459-68. Vikramasamvvat 1989-98. Īsvī san 1933-42. Ātmasaṃvat $36-42$. 
4. Candraprajñapti, this is a cosmological text which seems to have been lost, it was apparently of 9,500 ślokas in extent (Devendra Muni 1977, 525). The commentary by Malayagiri has also been lost with the text.

5. The Jìvajjivābhigama expands on the doctrine of "living" and "lifeless" things in 20 sections. This is a more or less a complete taxonomy of creatures and a description of the universe according to the Jaina view. The commentary on the Jìvajjivābhigama is a țikka , and either 14,000 granthas or 16,000 ślokas in extent (Velankar 1944, 144; Devendra Muni 1977, 525 and 529-30).

1883 *Atha-Sthānānga-nāmnas tṛtīyāngayopāngam Jìvābhigama-nāma sūtram / Śrī Malayagiri-Sūri-kṛta-vṛtti-sahitam Gurjara-bhāṣā-yuktam ca prārabhyate. Ahmedabad: Times Press, 1883.

1919 Śrīsthānāñāakhyatrtīyāingasambaddham Caturdaśapūrvadharaviracitam Śrimmanmalayagiryācāryasūtritavivaranayutam Śrīmajjīivājīivābigamopāingam [ / edited by Sāgarānanda]. Prathamasamskāre. Bombay: Sheth Devchand Lālabhāī Jaina Pustakoddhār Fund, Vīrasaṃvat 2445. Vikramanṛpasya 1975. Krāișța 1919.

6. The Nandī-sütra presents various traditions of epistemological discussion and interpretation. The commentary, the Nandi-sütra-tịk $\bar{a}$, mentions both the Nandīsutta Cürñi and Haribhadra's Vivarana and is 7,732 granthas in extent (Velankar 1944, 201; Devendra Muni 1977, 527). ${ }^{15}$

1878 Nandī-sūtra / Gaṇadhara-Sudharmāsvāmī-kṛta-mūla-sūtra tadupari Śrī-Malayagiri-kṛta-țīā, tadupari bhāṣā Valavodhasameta; Śrībhagavān Vijayasādhunā saṃśodhitaṃ. Kalikata: Nūtanasaṃskṛta Yantra, samvat 1935 [1878].

1917 *Śrīman-Malayagiry-Ācārya-vihita-vivarana-yutam ŚrīmadDevāvācaka-Gaṇi-drrbdham Śrīman-Nandī-sūtram ... Bombay: Nirṇaya-sāgara Press, Vikramasaṃvat 1974 [1917].

1924 Śrimanmalayagiryācāryapran̄itavrttiyutam Śrīmaddūṣsyagaṇiśișyācāryavaryaśrimaddevavācakakșamāśramaṇanirmitạ̣ Śìmannandīsūtram. Bombay: Agamoday-Samiti, Vīrasamvat 2450. Vikramasamvat 1980. San 1924.

\footnotetext{
${ }^{15}$ One manuscript of this commentary is dated 1235 CE (Winternitz 1933, 2: 592n1), while a section of the commentary (the refutation of theism) is given by F. C. Schrader, Über den Stand der indischen Philosophie zur Zeit Mahāvīras und Buddhas, p. 62 ff. (Winternitz, Ketkar and Kohn 1971, $2,472 \mathrm{n} 2$ ).
} 
* Nandisutram: Devavacakaviracitam: Malayagirikrtatikayah sankseparupa-Avacurya samalankrtam / samosadhakau VikramasuriPanyasasribhaskaravijayau. Surata: Devacanda Lalabhai Jainapustakoddhara Samstha, 1969. Ṭrasța, 2044 [1987].

7. The Oghaniryukti is a general treatment of the details of a monk's life: how to check items (for life forms), food, confession, atonement and so on. A commentary is mentioned in Devendra Muni $(1977,526)$ but no editions seem to have appeared.

8. The Pindaniryukti consists of around 700 verses ( $g \bar{a}$ thās) divided into eight chapters dealing with regulations about food for monks and nuns. The commentary by Malayagiri on the Pindaniryukti is about 6,700 granthas in extent but seems only to have been published once (Velankar 1944, 249; Devendra Muni 1977, 532). ${ }^{16}$

1918

Śrīmadbhadrabāhusvāmipran̄ìta-sabhāșyā-

śrimanmalayagiryācāryavivrtā Śrīpindaniryuktih / [edited by

Sāgarānanda]. Suratasițī: Devacandra Lālabhāī

Jainapustakoddhāraphaṇḍa, Isukhriste 1918.

9. The Prajñāpanā "gives in 36 chapters a classification of living beings, containing under 'human being' a geographical-ethnographic outline, in which the Aryans (ariya, ärya) and the barbarians (milikkha, mleccha) are enumerated with their habitations" (Winternitz 1933: 2, 456). This commentary is a Vrtti of 14,500 ślokas (Velankar 1944, 258) in which Malayagiri also discusses textual variants (Sirisāmajjavāyagaviraiyam Paṇnavaṇāsuttạn 1969, 426-31, 436-40).

1884

$$
\begin{aligned}
& \text { *Pannavan̄ā-sūtra: caturthopāniga [Gujarātī anuvāda sameta] } \\
& \text { prārambha / Loñkā-gacchīya Śrī Rāmacandra Gaṇikṛta } \\
& \text { Saṃskṛtānuvāda yuta; Nānakacandajī se saṃśodhita hoke mudrita }
\end{aligned}
$$

\footnotetext{
16 The commentary has been translated into Gujarati however: Śrutakevali Bhagavanta Śrī Bhadrabāhusvāmijì viracita Śrīpiṇdaniryukti grantharatnano: Malayagirijī viracita țīkārthayuta suviśuddha anuvāda / anuvādaka Haṃsasāgarajī. Bhāvanagara: Śrī Śāsanakaṇtoddhāraka Jñānamandira, 1962.
} 
huā; Kālikācarya saṅkalitasūtra, tadupari Malayagiri Sūri kṛta Saṃskṛta ṭikā aura Paramānandarṣi kṛta bhāṣā țîkā yuta. Benares: [s.n.], 1884.

1918-19 Śrimacchyāmācāryadṛbdham

Śrīmanmalayagiryācāryavihitavivaranayutam Śrīprajñāpanopāingam. Mehesana: Āgamodayasamiti, Vīrasamvat 2444-45. Vikramasamuvat 1974-75. Krāīșta 1918-19 (Reprinted 1988).

1988 Śrī Prajñāpanopāingam = Prajnaapanopaangam $/$ Purvadhara Śrī Śyāmārya viracitam; Malayagirisūri viracitavṛttiyutam; punarmudranaprerakāh Vijaya Bhuvanabhānusūríśvarāḥ. Cikapeța, Benggalora: Śr̄̄ Ādinātha Jaina Śvetāmbara Mandira Ṭrasța, 1988. (Reprint of 1918-19 edition).

10. The base text, the Rāyapasenaijja is a conversation between King Paesi and the monk Kesi about the nature of the soul. ${ }^{17}$ The Rājapraśniya-țika or -vrtti of around 3,600 granthas including text (Velankar 1944, 330). See also Devendra Muni (1977, 531-32).

1925 Śrīmatrājapraśnìyasūtram: Śrīmanmalayagiripranītavrttiyuktam. Bombay: Āgamoday Samiti, Vīra saṃvat 2451. Vikrama saṃvat 1981. Krāișta 1925.

1937 or 38 Rāyapasenaiya-suttam: pariśodhitamūlapātha-pāthāntara-vivaraṇatippana-viśiștāa-nekapariśiștâdibhih samyutam / sampādakạ̣ Becāradāsa Jīvarāja Dośí. Amadāvāda: Gūrjara Grantharatna Kāryālaya, Vi. sạ̣. 1994 [1937]. Vīra sạ̣vat 2464 [1938].

11. The Süryaprajñapti contains a systematic presentation of the astronomical views of the Jainas, it deals with both the sun and the moon and has an extent of 9,500 ślokas (Devendra Muni 1977, 525, 528).

1919 Śriman-Malayagiry-Ācārya-vihita-vivarana-yutam Śrī-Sūryaprajñapty-upāingam ... . foll. 4, [1], 297; 26 x 12 cm. Mahesānā: Āgamodaya Samiti, 1919.

${ }^{17}$ A study of the base text by Willem Bollée appeared in 2002 (The Story of Paesi (Paesikahānayam): soul and body in ancient India, a dialogue on materialism: text, translation, notes and glossary. Wiesbaden: Harrassowitz Verlag, 2002. (Beiträge zur Kenntnis südasiatischer Sprachen und Literaturen 8)). 
12. Viśeșāvaśyaka-(țīkā): not extant (Devendra Muni 1977, 526).

13. Vyavahāra-tikka, at around 33,625 granthas in extent this is Malayagiri's longest commentary (Velankar 1944, 367b). The base text concerns "procedures" to guide the life of Jain monks, i.e. a component of the Jain monastic code. See also Devendra Muni (1977, 530-31). One manuscript of this commentary is dated 1253 CE (Winternitz 1933, 2m 592n2).

1925-28 Śrī Vyavahāra-sūtram: Bhadrabāhūddharita-mūlasūtram Niryuktisametam, ... -bhāṣyam Śriman-Malayagiri-viracita-vivaraṇasametam / saṃśodhako Muni Māneka [or Mānikya].. [Ahmedabad]: Vakīl Keśavlāl Premcand [Modī]. saṃvat 1982-85. Sane 1925-28.

\section{9 Śrīcandra Sūri, fl. 1103-1171 CE ${ }^{18}$}

The excellent scholar Muni Punyavijaya has made the most comprehensive study of this minor commentator (Nandisuttam: Siridevavāyagaviraiyam. Aṇuogaddārāim ca: Siriajjarakkhiyatheraviraiyāim, sampādakāḥ Puṇyavijayo Muniḥ; Dalasukha Mālavaṇiyā, Amrtalāla Mohanalāla Bhojaka ity etau ca 1966, introduction in Hindi, 3-9) and I have drawn on his work extensively to compile the following summary. I have also added information from the entries in the Jinaratnakośa by Velankar (1944) and in the Jaina Sāhitya kā Bṛhad Itihāsa (1966, 3, 449-51). The praśastis which provide the raw material concerning Śrīcandra are cited in full by Punyavijaya. ${ }^{19}$

Muni Punyavijaya attributes seven Sanskrit commentaries written between 1112 and 1171 to Srīcandra. Most are short works on sections of texts rather than attempts to provide comprehensive guides to larger texts, they are derivative commentaries, mostly repeating glosses and explanations from the earlier teachers

\footnotetext{
${ }^{18}$ The Pindanijjutti commentary by Vīraganin, who belonged to the Candra gaccha, was edited in Pātan by Nemicandra Sūri and Jinadatta Sūri in samvat 1160 [1103] or 1169 [1112]. Monks named Mahendra Sūri, Pārśvadeva Gaṇin and Devacandra Gaṇi assisted the author (Piṇ̣Ni.1958, Prakāśakīya nivedana, p. 3; (Velankar 1944, 249)). It seems possible this Pārśvadeva Ganin could be the same as the one who became Śricandra (this is discussed below), and I have therefore expanded the date range for Śrīcandra suggested by Punyavijaya-1112-71- to include this possibility, i.e. I suggest his dates of composition may be 1103-71.

${ }^{19}$ There is another author named Śīcandra of the $12^{\text {th }}$ century, he belonged to the Harsapuriya gaccha and wrote a work entitled Sängrāhaṇisūtra.
} 


\section{Jìtakalpa-brhaccūrni-vișamapada-vyākhyā}

This is an explanation of the difficult places (vișama-pada) in Siddhasena Gani's Jitakalpabrhaccūrni, which is in turn a work commenting on the Jiyakappa of Jinabhadra. The last named is a work on monastic discipline written in around 588 CE. The commentary has been published once, in the publication listed below ( $\mathrm{p}$. 31-59). The colophon confirms some of the details in the lineage chart for Śrīcandra. It gives the date of composition as samvat 1227, i.e. 1170 or 1171 CE.

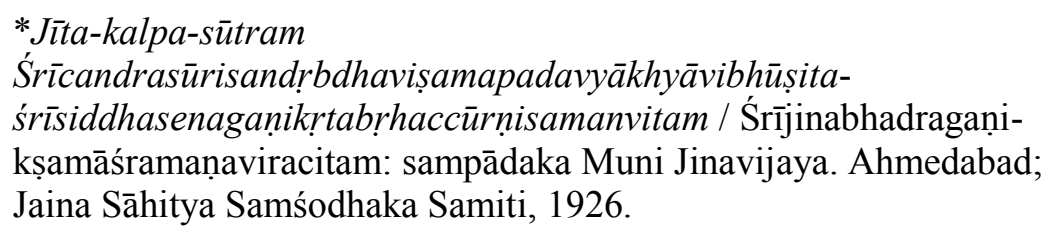

\section{Nandīsūtra-laghuvrtti-durgapada-vyākhyā}

This is a brief commentary on Haribhadra Sūri's Vivarana to the Nandī-sütra. It picks out very occasional words for comment, and when printed it occupies only five pages. The colophon is short and does not give a date, however, the oldest extant manuscript of this work is held in Jaisalmer and includes an indication that the text was copied in samvat 1226, dvitīya Śravana, śudi 3, Soma which matches Monday July 28, 1169 (Caitrādi). This work was therefore copied during the lifetime of Śrīcandra, but for a monk of the Jālyodhara gaccha. This manuscript is exceptionally clear (ati-śuddha) and formed the basis for Punyavijaya's editon of this work in 1966. It is also called Vrtti-tippana (grantha 3,300), and Durgapadavyākhyā (Vekankar 1944, 201)

1966 Nandisūtram: Śrī-Śrīcandrācāryakrtadurgapadavyākhyāajñātakartṛavișamapadaparyāyā-bhyām samalañkrtayā Ācārya śrīharibhadrasūrikṛtayā Vrttyā sahitam / samśodhakạ̣ sampādakaś ca Munipuṇyavijayaḥ. Vārāṇasī: Prākṛta Grantha Pariṣad, Vīrasaṃvat 2493 [1966].

1969 *Nandisūtram: Devavacakaviracitam: Malayagirikrtațīkāyāh sankșeparūpa-Avacūrya samalaikkrtam / samosadhakau VikramasuriPanyasasribhaskaravijayau. Surata: Devacanda Lalabhai Jainapustakoddhara Samstha, 1969. 


\section{Nirayāvalikā-vivarana}

The commentary on the narrative text, the Nirayāvaliya-suyākkhandha is ascribed to Śrīcandra on the basis of the colophon verse found in some of the oldest palm leaves.

Punyavijaya saw this colophon as sufficient authority to assign authorship to Śrīcandra. Certainly the fragmentary nature of the commentary would make it in keeping with the other commentaries assigned to this commentator. If we accept the tradition of the date this work is also the last known extant work of Śricandra and was written perhaps near the end of his life. The praśasti gives only the year samvat 1228, ie. 1171 or 1172 . The manuscripts favour its title being Nirayāvaliyā-suyakkhandha-vivarana rather than -vrtti as suggested by Muni Punyavijaya.

1885 Nirayāvaliyā sūtra prārambhah: bhāga 19 Kappiyā, 20

Kappavidamsiyā 21 Pupphiyā, 22 Pupphacūlā, 23 Baṇhidasā / Śrī Gaṇadhara Sudharmā Svāmi sañkalita sūtra, tadupari Candra Sūri kṛta Saṃskṛta țîkā; Sadāranga kṛta bhāṣā țīkā yuta; Paṇịita Viśvanātha jī se saṃśodhita. 1. daphe. Banārasa: Jaina Prabhākara Presa, saṃvat 1941. San 1885 Īsavī.

1922 Śrīnir [a]yāvalikāsutram / Śrīcandrasūriviracitavṛttiyutạ̣; Dānavijayagaṇibhị̣ saṃśodhitam. Amadāvāda(rājanagara)madhye [Ahmedabad]: Rājanagarastha Śrīvīrasamājạ̣, Vīrasaṃvat 2448. Vikramasamvat 1979. San 1922.

1934 The Nirāvaliyāo, the last five Upangas of the Jain canon = Niggam thapāvayanesu [sic], carimapañcovañgabhūyāo Nirayāvaliyāo: edited with introduction, translation, notes, glossary appendices and critical foot-notes [includes the commentary] / by A[mritlal]. S[avchand]. Gopani and V. J. Chokshi. Ahmedabad: Gurjar Granth Ratna Karyalaya, 1934.

\section{Niśîtha-cūrnii-durgapada-vyākhyā}

This is a commentary on difficult sentences and words in the twentieth uddeśaka of the Viśeșa-cūrṇi on the Niśitha.

1922 Sthavira-pungava Śrī Visāhagaṇi Mahattara-pranītam, sabhāṣyam Nisítha-sūtram: Ācāryapravara Śrī Jinadāsa Mahattara-viracitayā Viśeșa-cūrnya samalaìkrtam / sampādaka Amaramuni tathā 
Kanhaiyālāla. Dillī: Bhāratīya Vidyā Prakāśana ; Āgarā: Sanmati Jñāna Pîṭha, 1982. Dvitīya samśodhita samskaraṇa. ${ }^{20}$

An opening verse explains, in clichéd terms, the reasons for writing the commentary: viṃśoddeśe Śrīniśíthasya Cūrnau, durgam vākyam yat padạn vā samasti / svasmrtyartham tasya vaksye subhodhām, vyākhyām kāmcit sadgurubhyo'vabuddhäm // 2 // "Whatever difficult sentence or word there is in the twentieth uddeśa of the Nisítha-cürni, for the sake of my own memory I will relate about it something of an easily understood commentary, learnt from the true teachers." This work was written in samvat 1174, i.e. $1117 \mathrm{CE}$, according to its colophon, where an exact date is given. The author calls himself Śīcandra and refers to Śîlabhadra Sūri as his teacher, omitting any mention of Dhaneśvara Sūri. Punyavijaya has interpreted this colophon to show that this is the first extant work known which Śrīcandra wrote after becoming a Sūri and changing his name from Pārśvadeva Gaṇi (Nandisuttaṃ: Siridevavāyagaviraiyam. Aṇuogaddārāim ca: Siriajjarakkhiyatheraviraiyāim / Sampādakāh Punyavijayo Munih; Dalasukha Mālavaniyā, Amrtalāla Mohanalāla Bhojaka ity etau ca 1966, 5). This would mean that event took place sometime between 1112 and 1117 .

\section{Nyāyapraveśa-pañjik $\bar{a}^{21}$}

The Nyāyapraveśa-pañjika is a sub-commentary on the commentary (țika $\bar{a})$ of Haribhadra Sūri to the well-known logic text by the Buddhist Dinnāga, the Nyāyapraveśa. It is the earliest known dated work by Srīcandra and, according to the colophon (cited in full by Punyavijaya). It was completed on Phālguna krșna 9, samvat 1169, during the nakșatra Anurādhā: this is Friday, 23 February, 1112 (Karttikādi). ${ }^{22}$

1968 The Nyāyapraveśa: part 1 Sanskrit text with commentaries [of Haribhadra and Śrícandra (Pārśvadevagani)]: critically edited with notes and introduction / by Anandshankar B. Dhruva. Baroda: Oriental Institute, 1968. (Gaekwad's Oriental series; no. 38). (Reprinted from the 1930 edition).

\footnotetext{
${ }^{20}$ Śñ̄candra's work is in v.4 (p. 413-43). Details of the first printing not traced.

${ }^{21}$ A pañjika is, in theory at least, a commentary that explains every word in a text Āpte s.v.).

${ }^{22}$ Dhruva interprets the dates a little differently, I follow Pumyavijaya because of his specialized study of this commentator.
} 
Punyavijaya states that all the old as well as modern manuscripts of the Nyāyapraveśa-pañjikā mention Pārśvadevagaṇin as its author. The fact, however, that this Pārśvadevagaṇin was identical with Dhaneśvarasūri's disciple of that name who, after attainment of the status of a Sūri, became famous as Śrīcandra Sūri, the esteemed author of a number of works, is known only from the praśasti, at the close of the palm leaf manuscript of the Pañjika preserved in a collection at Pātana. The praśasti indicates that Pārśvadeva Gaṇi (= Śrīcandra) was the pupil of Dhaneśvara Sūri. A commentary by this Dhaneśvara Sūri on Jinavallabha Sūri's Sārdhaśatakaprakarana (= Sūkșmārthavicārasāraprakarana) is extant, and its praśasti provides further information on Pārśvadeva Gaṇi's lineage.

The Candra kula to which this author is connected was "a prestigious lineage apparently dating from early medieval times which later Śvetāmbara sectarian groups attempted to incorporate into their own traditions." Abhayadeva also describes himself as belonging to this lineage (Dundas 1996, $95 \mathrm{n} .43$ referring to 1993, 258 n.66). This suggests Abhayadeva may have been a predecessor in Śrīcandra's scholastic lineage.

\section{6. Śrāddhapratikramanasūtra-vrtti}

This commentary is on a text forming part of the Sadāvaśyakasūtra (Velankar 1944, 390). There are more than a dozen other commentaries of various kinds on this text, which consists of fifty gāthās (389-91). I have not traced any published version of this work. The date of completion given in verse 8 of the colophon is samvat 1222, Madhu (= Caitra), śukla 10, nakșatra Pusya, Dhrti yoga, which is Sunday March 13, 1166 (Kārtikādi). It is notable that a palm leaf manuscript dated samvat 1299 exists in Pātana i.e. it dates from only seventy years after the commentary was completed. Early copies of Śrīcandra's works are wellrepresented in Pățana collections, which may even suggest he was based in the area of Northern Gujarāt.

\section{7? $\quad$ Pindaviśuddhiprakaraṇa-vrtti}

This is a commentary on Jinavallabha Sūri's Pindaviśuddhi (250). According to the colophon it was composed in samvat 1178, 1121 or 1122 CE. However as Punyavijaya points out the use of the name Śrīdevatā in the colophon does not fit 
with the other colophons by Śrīcandra and whether or not we can confidently include this amongst his works is as yet unresolved.

\section{8? Subodhā-samācārī}

I have not been able to discover much about this work. According to the colophon it is written in Prākrit, whereas none of Śrīcandra's other works have been. Again, the colophon matches the lineage information already established, Velankar (1944, 431-32) lists this as one of two dozen texts entitled Sämācāri which suggests there may be some difficulty in telling them apart.

1924 Śrīsubodhāsamācārī / Śrīmacchrīcandrācārya-sañkalitā. Bombay: Śreșthī Devacandra-Lālabhāī-Jaina-Pustakoddhāra Fund, Bhagavanmahāvīranirvāṇasamvat 2450. Krāisța san 1924. Vikrama samvat 1980.

1988 *Śrīsubodhā-sāmācārī / Śrīcandrācāryasañkalitā. Mumbaī: Śrī Jinaśāsana Ārādhanā Ṭrasṭa, 2045 [1988].

1993 *Sāmācārī prakaranam:

Purvatarakālīnaśrīmadācāryapurandaravihitam: śrīmacchrīcandrācārya-sañkalitā Śrīsubodhāsāmāēārī ca / sampādakạ̣ samśodhakaś ca Vijayajinendrasūríśvaraḥ. Prathamāvṛttị̣. Lākhābāvala, Śāntipurī, Saurāșțra: Śrī Harșapuṣpāmṛta Jaina Granthamālā, 1993.

Punyavijaya points out that the Brhattippanika attributes other works to him also, namely Jayadevachandahssástravrtti-țippanaka and Sanatkumāracarita (written in samvvat 1214), but no copies of these works have yet been discovered (Prastāvanā 7).

\section{References}

Acharya, Diwakar. 2007. "The Original Paṇhavāyaraṇa / Praśnavyākaraṇa discovered.” International Journal of Jaina Studies (Online) 3 (6): 1-10.

http://www.soas.ac.uk/research/publications/journals/ijjs/file40439.pdf

Alsdorf, Ludwig. 1977. "Jaina Exegetical Literature and the History of the Jain Canon.” In Mahāvīra and and His Teachings. Bombay: Bhagavān Mahāvīra 2500th Nirvāṇa Mahotsava Samiti.

Balbir, Nalini. 1993. Avvaśyaka-Studien: Introduction Générale et Traductions. Stuttgart: Franz Steiner. 
Bronkhorst, Johannes. 1999. "Review of Willem B. Bollée's Brhatkalpaniryukti and Brhatkalpabhāsya: Romanized and Metrically Revised Versions, Notes from Related Texts and a Selective Glossary. Stuttgart: Franz Steiner, 1998." Asiatische Studien= Études Asiatiques 53: 987-92.

Devendra, Muni. 1977. Jaina Āgama Sāhitya: Manana aura Mīmāmsāa: Jaina Vāingmaya Kà Paricayātmaka Adhyayana $=$ A Panoramic Study of Jain Canonical Literature with Comparative Study of Relevant Buddhist and Vedic Texts. Udayapura, Rājasthāna: Śrī Tāraka Guru Jaina Granthālaya.

Doshi, B. Malayagiri’s Śabdānuśāsana. 1967. Ahmedabad: Lalbhai Dalpatbhai Bharatiya Sanskriti Vidyamandira.

Dundas, P. 1996. "Somnolent Sūtras: Scriptural Commentary in Śvetāmbara Jainism." Journal of Indian Philosophy 24: 73-101.

Hoernle, Rudolf A F. 1880. The Uvāsagadasāo, or, the Religious Profession of an Uvāsaga, Expounded in Ten Lectures, Being the Seventh Anga of the Jains, Edited in the Original Prākrit with the Sanskrit Commentary of Abhayadeva [and English Translation]. Calcutta: Asiatic Society of Bengal.

Jain, Jagdishchandra. 1984. Life in Ancient India as Depicted in the Jain Canon and Commentaries: 6th Century BC to 17th Century AD. New Delhi: Munshiram Manoharlal.

Jaina Sāhitya kā Bṛhad Itihāsa. 1966. Edited by Dalasukha Mālavaṇiyā and Mohanalāla Mehatā. Vārāṇasī: Pārśvanātha Vidyāśrama Śodha Saṃsthāna.

Jyväsjärvi, Mari. 2010. Retrieving the Hidden Meaning: Jain Commentarial Techniques and the Art of Memory, Journal of Indian Philosophy 38: 133-62

Kapadia, Hiralal Rasikdas. 1935. Descriptive Catalogue of the Government Collections of Manuscripts Deposited at the Bhandarkar Oriental Research Institute. V. 17: Jaina Literature and Philosophy. Agamika Literature. Poona: Bhandarkar Oriental Research Institute.

- 2000. The Canonical Literature of the Jainas. First reprint ed. Ahemdabad, India: Sharadaben Chimanbhai Educational Research Centre.

Kapadia, Hiralal Rasiklal. 1935. "The Jaina Commentaries.” Annals of the Bhandarkar Oriental Research Institute 16 (1934-35): 292-312.

Khadabadi, B. K. 1991. "Reflections on the Jaina Exegetical Literature." In Aspects of Jainology: Pt. Dalsukh Bhai Malvania felicitation volume, edited by M. A. Dhaky and S. Jain, Vol. 3, 27-33. Varanasi: P. V. Research Institute.

Leumann, Ernst. 1934. Übersicht über die Avasyaka-Literatur: aus dem Nachlass herausg. von Walther Schubring. Hamburg: Friederichsen, de Gruyter.

Nandisuttaṃ: Siridevavāyagaviraiyaṃ. Aṇuogaddārāim ca:

Siriajjarakkhiyatheraviraiyāim / sampādakāh Punyavijayo Muniḥ; Dalasukha Mālavaṇiyā, Amrtalāla Mohanalāla Bhojaka ity etau ca. 1968. Bambaī: Śr̄̄ Mahāvīra Jaina Vidyālaya. 
Nandisuttaṃ: Siridevavāyagaviraiyam. Aṇuogaddārāim ca:

Siriajjarakkhiyatheraviraiyāim / sampādakāh Punyavijayo Muniḥ; Dalasukha Mālavaniyāa, Amrtalāla Mohanalāla Bhojaka ity etau ca. 1966. Bambaī: Śrī Mahāvīra Jaina Vidyālaya.

Norman, Kenneth R. 1997. “The Jaina Nijjuttis.” Acta Orientalia 58: 52-74.

Prana Natha and Chaudhuri, Jitendra Bimala. 1938. Catalogue of the Library of the India Office. 1938-57. Volume 2, Part 1 (Revised Edition). Sanskrit Books. Revised edition ed. London: HMSO.

Punyavijay, Muni. 1961. Catalogue of Palm-leaf Manuscripts in the Śāntinātha Jain Bhanḍ̄ara, Cambay. Baroda: Oriental Institute.

Sirisāmajjavāyagaviraiyam Paṇnavaṇāsuttaṃ. 1969. Bambaī: Śrī Mahāvīra Jaina Vidyālaya.

Schubring, Walther. 1935. Die Lehre der Jainas nach den Alten Quellen Dargestellt. Berlin: Walther de Gruyter.

—. 1944. Die Jaina-Handschriften der Preussischen Staatsbibliothek: Neuerwerbungen Seit 1891 / Unter Redaktioneller Mitarbeit Von Günter Weibgen. Leipzig: Otto Harrassowitz.

Tieken, Herman. 1986. “Textual Problems in an early Canonical Jaina Text.” WZKS 30: 525.

Tripāṭh̄̄, Chandrabhāl. 1981. "The Jaina Concordance in Berlin: a Bibliographical Report." In Studien Zum Jainismus und Buddhismus: Gedenkschrift für Ludwig Alsdorf I Herausgegeben von Klaus Bruhn und Albrecht Wezler. Wiesbaden: Franz Steiner.

Velankar, Hari Damodar. 1944. Jinaratnakośa: an Alphabetical Register of Jain Works and Authors (vol. 1 Works (no more published)). Poona: Bhankarkar Oriental Research Institute.

Williams, R. 1965. "Haribhadra.” BSOAS 28 (1): 101-11.

Winternitz, Moritz, S. V. Ketkar, and H. Kohn. 1933 [1971]. A History of Indian Literature. Volume 2: Buddhist Literature and Jaina Literature: translated From the Original German. Calcutta: University of Calcutta. 